\title{
A Review of Recent Trends in Sustainable Fashion and Textile Production
}

\author{
Rajkishore Nayak*1, Amanpreet Singh², Tarun Panwar ${ }^{2}$ and Rajiv Padhye ${ }^{2}$ \\ ${ }^{1}$ School of Communication and Design (Fashion Merchandising), RMIT University Vietnam, Australia \\ ${ }^{2}$ School of Fashion \& Textiles, RMIT University, 25 Dawson Street, Australia
}

Submission: December 18, 2018; Published: February 07, 2019

*Corresponding author: Rajkishore Nayak, School of Communication and Design (Fashion Merchandising), RMIT University Vietnam, 702 Nguyen

Van Linh, District 7, Ho Chi Minh, Vietnam, Australia

\begin{abstract}
Fashion and textile products evolve through several processes that involve the conversion of fibre to yarn, yarn to fabric and fabric to garment. During these processes, there are numerous evidences from the past that the fashion and textile producers are not giving much attention to sustainable practices. With the growing global interest on sustainability and increased consumer awareness, fashion and textile industries have taken initiatives to offer sustainable solutions in their production lines. There are a number of approaches taken by the stakeholders in the fashion production starting from fibre production to garment manufacturing even the supply chain management to fulfil the sustainability requirements. Fashion items produced using sustainable practises can contribute to environmental, social, and economic well-being leading to a green earth in the future. This review presents the data and findings collected from relevant "review and research articles" relating to sustainable fashion and textile production that are available in selected databases. This paper reviews the recent trends in the sustainable fashion and textile production in various stages of fibre, yarn, fabric and garment manufacturing. Furthermore, the roles played by various governing bodies, manufacturers and retailers including the consumers for producing "sustainable fashion and textiles" are also discussed..
\end{abstract}

Keywords: Sustainable fashion design; Slow fashion; Ecofriendly textile processes; Fast fashion, Social accountability, Life cycle assessment

\section{Introduction}

Sustainability issues are gaining impetus in several manufacturing sectors including fashion and textiles due to increased consumer awareness and stricter global legislations [1-3]. Until recently several fashion manufacturers were taking the advantage of lenient regulations and lower environmental awareness in developing countries to achieve low production cost [4]. The allied industries for the production fashion as well as fashion accessories are struggling with varying degree of environmental and social problems [5]. The inherent nature of fashion production largely impacts the environment due to large amount of energy and water consumption; greenhouse gas emission; hazardous waste generation; and discharge of toxic effluent containing dyes, finishes and other chemicals to the ecosystem [6,7]. The social impacts of fashion production include use of child labour, poor working conditions, long working hours, low wages and health and safety risks [8].

Fashion products can be classified as fast and slow. The concept of fast fashion is alluring to many consumers who like to change their fashion style frequently, thus compromising sustainable production. Corporations such as Zara, Uniqlo and
H\&M have an emphasis on fast fashion to fulfil consumers' demands. Although many consumers today are conscious of sustainability from a young age, the continual increased demand for newer fast fashion results in a mass consumer that generates piles of waste cloth. However, slow fashion (a process using sustainable production methods and greener technologies) meets the expectations of social responsibility and environmental sustainability. The movement to achieve sustainable fashion is rather a slow process as there are complexities involving several manufacturers and a lot of idealism [9].

Textile and fashion production have a negative impact on the environment. Firstly, natural and synthetic fibres used as raw material need a substantial amount of water and energy for their production, respectively. Secondly, there is significant environmental impact during fabric chemical processing, which uses large quantities of chemicals, auxiliaries, energy and water leading to the generation of significant amount of effluent. Thirdly, substantial amount of water and energy are consumed for the care and maintenance of clothing during their use. Finally, at the end-of-life (EOL) of the fashion and textile products, the 


\section{Current Trends in Fashion Technology \& Textile Engineering}

options of landfilling or recycling create environmental impact [10].

Several approaches can be taken to achieve sustainable fashion and textile production, starting from the selection of raw materials to the EOL of a product. Sustainable fashion production involves ecofriendly and non-depleting material selection; environmentally friendly manufacturing processes; green supply chain, distribution and retailing; and ethical consumers $[11,12]$. Fabric chemical processing, with the greatest environmental impact can be made greener by adopting newer technologies such as use of enzymatic processing; plasma applications; and use of advanced chemicals and auxiliaries. In addition to the environmental sustainability, fashion industries need to fulfil its other pillars, social and economic sustainability, to achieve complete sustainable fashion production, which is discussed in detail in this review.

There are several initiatives taken by the fashion and textile producers to achieve sustainable production. In this review, various aspects of "sustainable fashion and textile production" such as environmental, social and economic are broadly discussed. Using existing data from a variety of sources, this review primarily discusses the approaches taken by fashion and textile manufacturers in material selection, manufacturing, waste management and recycling of fashion products. Fashion products' "life cycle assessment (LCA)", reuse and recycling approaches are also highlighted. Additionally, the paper reviews the roles played by various governing bodies, manufacturers, retailers and consumers, including the international standards for sustainable fashion and textile.

\section{Study Design}

This paper was prepared using information from the collection of review and research articles available in different databases, such as Google Scholar, Web of Science, Scopus, EBSCOhost, and Sci-founder. The database search was based on the keywords used in the context of sustainable fashion and textile production. Major keywords that were used included: "sustainable fashion", "sustainable textile", "ecofriendly textile processes", "textile effluent treatment", "fashion and social accountability", "fashion/textile products" combined with "life cycle assessment", "green fashion", "green supply chain" combined with "fashion/ textiles" and "green textile production".

The timeframe was primarily based on the last 15 years of work, but in some cases earlier papers were also included, as they were relevant to the review. The type of papers included mainly published articles in various journals, conference proceedings, and research theses (Masters and $\mathrm{PhD}$ ). In some instances, creative sustainable works produced by fashion institutes and newspaper blogs were also included. A total of 217 articles were collected and closely inspected for their abstract and research outcomes. Out of these, a total of 180 articles were selected for the study, as the remaining papers did not fully align with the primary focus area of this review.
Initially the papers were classified into three groups based on the three sustainability pillars they were covering, such as:

(i) Environmental

(ii) Social

(iii) Economic

Table 1: Grouping of articles based on the area of research relating to sustainable fashion.

\begin{tabular}{|c|c|c|c|}
\hline Category & Subgroups & $\begin{array}{c}\text { Number of } \\
\text { papers }\end{array}$ & $\begin{array}{c}\text { Percentage of } \\
\text { papers }(\%)\end{array}$ \\
\hline \multirow{3}{*}{$\begin{array}{l}\text { Environ- } \\
\text { mental } \\
\text { [74] }\end{array}$} & $\begin{array}{l}\text { Green and sustainable } \\
\text { practises in garment } \\
\text { production }\end{array}$ & 17 & 14.7 \\
\hline & $\begin{array}{c}\text { Green and sustainable } \\
\text { practises in textile pro- } \\
\text { duction }\end{array}$ & 25 & 21.6 \\
\hline & $\begin{array}{l}\text { Sustainable practises for } \\
\text { treating and evaluating } \\
\text { effluents }\end{array}$ & 32 & 27.6 \\
\hline \multirow{3}{*}{$\begin{array}{c}\text { Social } \\
{[29]}\end{array}$} & $\begin{array}{l}\text { Workplace related, such } \\
\text { as work practise, facili- } \\
\text { ties, light, amenities, tools } \\
\text { and working aids }\end{array}$ & 13 & 11.2 \\
\hline & $\begin{array}{l}\text { Workforce related, such } \\
\text { as incentives and rewards }\end{array}$ & 10 & 8.6 \\
\hline & $\begin{array}{l}\text { Enhancing skill by train- } \\
\text { ing and workshops }\end{array}$ & 6 & 5.2 \\
\hline \multirow{4}{*}{$\begin{array}{l}\text { Econom- } \\
\text { ic [13] }\end{array}$} & $\begin{array}{l}\text { Related to business strat- } \\
\text { egies and profitability }\end{array}$ & 5 & 4.3 \\
\hline & $\begin{array}{c}\text { Related to economic } \\
\text { development }\end{array}$ & 3 & 2.6 \\
\hline & $\begin{array}{l}\text { Related to resource con- } \\
\text { sumption }\end{array}$ & 5 & 4.3 \\
\hline & Total & 116 & 100 \\
\hline
\end{tabular}

Subsequently, based on their content, they were classified into subgroups, as shown in Table 1.

It can be seen from Table 1 that majority of publications were on sustainable fashion and textile addressed environmental aspects, which was about $64.8 \%$. In this category, the maximum number of publications was targeting the effluent production and treatment, followed by the alternative techniques used to produce sustainable fashion. Social accountability recorded the second highest number of publications (25\%), whereas economic development was the lowest, with only $11.2 \%$ of the papers.

\section{Sustainable Fashion and Textile Design}

One of the key challenges faced by the fashion textile industries is adopting sustainability in product manufacturing. Sustainability focuses on the "triple bottom line": environmental social and economic, impacts of a product or service [13]. From a sustainability perspective, fashion and textile products are considered to be inherently at odds with the production process, as designers and product developers face several challenges to 
streamline a style. This section focuses on the requirements, fashion consumption and consumer attitude relating to sustainability in fashion and textiles.

\section{Requirements of Sustainability}

Due to the inherent nature and fast-pace of the fashion industry, several fashion manufacturers in the past have used unsustainable practices to meet demand and gain increased profitability. As there is an increased global trend towards sustainable fashion, many of the current fashion brands are now adopting sustainable practises in the three pillars of sustainability [14]. The most important sustainability factor is the environmental impact created during the production of fashion and textile items. Furthermore, the social accountability and economic aspects of in fashion and textile production is neglected in many countries, which is a global concern. It is believed that the fashion items produced by sustainable practises can alleviate the ecological and social strains in addition to providing an ethical choice for sustainable-conscious consumers to buy sustainable product [15].

\section{Fashion Consumption and Consumer Attitude}

Consumers in developed countries discard fashion items more often, even though the items are still useful [16]. The "throwaway culture" has been developed as a result of easy availability of low-priced high street clothing and the success of the major brand retailers. The reusability of these garments is reduced if they are out of fashion, poor in aesthetics, and lose their dimensional stability and durability [17]. If not reused, these garments meet with landfill or generation of bondawaste, depending on the degree of wear, physical condition, type of garment and fibre composition. The economic viability of recycle and reuse depends on the infrastructure and technology available for recycling.

Birtwistle and Moore [18] explain that early fashion innovators or early adopters, which accounts for about $16 \%$ of consumers, are highly influenced by fashion trends. They buy new fashion items more quickly and use them for socializing only a few times and then discard them leading to "throwaway fashion" [18]. The concept of "throwaway fashion" plays a major role in global sustainability. Over the last decade, the concept of fast fashion has revolutionized the fashion industry, where new fashion styles are available every week $[19,20]$. Easy access to the fast fashion stores online and at a competitive price has especially helped young female consumers to fulfil their demand for new fashion styles [16]. In addition, fast fashion retailers such as Zara, Benetton, H\&M and Topshop are now selling fashion items at competitive prices that are designed to be used less than 10 times then becomes a "throwaway fashion" [21].

To address the "throwaway culture", consumer ethics has played a significant role in recent years [22]. Ethical consumers consider the impact of consumption of a product on the environment, humans, and animals [23]. Although ethical consumers are focusing on sustainable products and practices, research evidence shows that many consumers are yet to adopt these practises for certain products [24,25]. Indeed, when fast fashion is considered, consumer awareness of sustainability techniques is found to be low. For example, it is often difficult for consumers to use ethical practises in their fast fashion product consumption, as information is hard to find. Hence, the concept of sustainable fashion becomes 'unfashionable' which can increase the disposal of fashion products after only limited use [16].

The concept of slow fashion, on the other hand, helps consumers to consider the economic models and sustainable practices related to fashion production, distribution and use [26]. It helps consumers to pay attention to "valuing and knowing the object" [27] and integrates experience with selfenhancement values [28]. The slow fashion approach avoids several negative factors related to fast fashion, in particular, large volumes of waste, and not paying attention to the environment [29]. Clark [29] mentions that the approach of slow fashion is just the opposite of fast fashion. Slow fashion offers better sustainable solutions that have a direct and positive impact on design, production, consumption, and use [26]. The slow fashion approach is based on the practises of food production and consumption for a sustainable living [30].

Successful consumer adoption of sustainable fashion depends on consumer awareness through education on reducing waste and environmental impact. Furthermore, understanding the consumer's ethical values and the complex driving factors can provide key guidelines for sustainability in fashion products [31]. Recent research demonstrates that barriers such as lack of consumer awareness, inappropriate retail environment, and social norms impact on the movement towards "eco-conscious fashion acquisition" [32].

\section{Environmental Sustainability}

The global consumption of fashion and textiles is ever growing, which creates challenges to the environment [10]. In order to achieve low cost production, the fashion manufacturers in developing countries take advantage of lack of strict regulations and lower environmental awareness, which hinders environmental sustainability [33]. For achieving sustainable fashion and textile production, the fashion manufacturers should focus on the sustainability aspects of production and follow the sustainability guidelines outlined in the ISO 14000 and other environmental management standards. The following section describes the approaches such as selection of raw materials, ecofriendly processes, product life cycle assessment and recyclability to achieve environmental sustainability in fashion and textiles.

\section{Raw Material Selection}

While selecting raw materials for fashion and textile production, the objective should focus on renewable (natural 
fibres such as cotton, flax, wool and silk) and recyclable materials (fibres such as recyclable polyester and nylon). As the synthetic fibres are not biodegradable, hence must be selected so that they are recyclable at the EOL to minimize accumulation of waste. The use of blends such as synthetics and natural fibres should be avoided as it is rather difficult to recycle a blend compared to the single fibre. The natural fibres are not inherently green. For example, the widely used natural fibre cotton, although biodegradable, its production requires a substantial amount of fresh water. The water consumption for the production of synthetic fibres is significantly lower (about 1/10) compared with cotton. For example, acrylic fibre needs $0.3-15 \mathrm{~L} / \mathrm{kg}$ of water [34], whereas cotton fibres need $200 \mathrm{~L} / \mathrm{kg}$. However, the production of synthetic fibres consumes a higher amount of energy. For example, the polymerisation, spinning and finishing of fibres consumes $369-432 \mathrm{MJ} / \mathrm{kg}$ of fibre production, whereas the production of cotton requires much lower energy, in the range of 38-46MJ/kg of cotton [34]. Production of cotton fibre consumes substantial amount of synthetic fertilizer, the seeds are treated with insecticides, herbicides applied to control weed growth and pesticides applied for pest control. Approximately $26 \%$ of world's insecticides are used in conventional cotton production [35]. Many of the synthetic chemicals contribute to acute toxicity, which can deteriorate soil quality and potential drift into neighboring committees. On the other hand, organic cotton reduces soil and water pollution in addition to its superior properties such as free from allergic reaction, soft feel. Organic cotton heals the planet, supports a true economy and protects our health.

In the last two decades the technological developments in polymer science have resulted in the commercial production of fibres such as soya, bamboo and polylactic acid (PLA), which are prepared from renewable biological sources and biodegrade after disposal [36]. These fibres provide a solution to the recycling problems involved with synthetic fibres [37]. The clothing prepared from soya fibres has softness similar to cashmere and elastic handle, but it is less durable than cotton. Similarly, bamboo is a resilient and durable fibre, with a high breaking tenacity, better moisture-wicking properties and better moisture absorption, compared to cotton [38]. The advantage of bamboo fibre compared to cotton is no use pesticides or fertilizers when growing bamboo. In addition, the EOL bamboo clothing can be disposed in an eco-friendly manner. PLA is a thermoplastic aliphatic polyester fibre prepared from corn starch or sugarcane. PLA fibre can be used as compost and it degrades rapidly at EOL.

\section{Ecofriendly Processes}

The conventional fashion and textile manufacturing practises based on non-renewable energy sources (gas, coal or petroleum) are unsustainable due to their limited availability and waste production that creates environmental burden. As the term "green production" is becoming important in many of the manufacturing segments, fashion and textile producers and retailers are adopting the terms "green production". Vachon and Klassen [39] mentioned that the green production practises can help industries to achieve the economic benefits of having a higher number of target customers, and to achieve 'the edge' over their competitors. Emerging technologies (sol-gel, layer-bylayer deposition, enzyme processing and plasma deposition) and materials (nanomaterials), are paving the way for sustainable fashion production [40-43]. Sustainable practises in yarn, fabric and garment manufacturing are discussed in the following section.

\section{Yarn and Fabric Manufacturing}

Yarn and fabric manufacturing are mechanical processes that need large amount of energy, generate waste, dust and noise [44]. The total energy consumption in a textile industry can be split as $34 \%$ in spinning, $23 \%$ in weaving, $38 \%$ in chemical processing and $5 \%$ in other miscellaneous processes. But the more interesting fact is that the energy consumed during the care and maintenance of a cloth is almost four times (75-80\%) compared to the energy consumed for its production (15$20 \%$ ) [45]. The global emphasis on sustainability has led to the development of yarn and fabric manufacturing machines that uses less energy, works with higher efficiency and generates less dust and noise. As a result several new techniques have evolved in spinning (such as open-end rotor and air jet spinning), weaving (rapier, projectile, air jet, multi-phase and waterjet looms) and knitting (high speed circular knitting, computerized flatbed machine, seamless knitting).

Yarn manufacturing processes such as ring spinning, rotor spinning and air jet spinning are energy intensive [46]. Among these, ring spinning uses maximum amount of energy, hence, imparts highest amount of environmental load. Increase in the spindle speed (a challenging task), efficient driving system, lightweight bobbins, advanced ring and traveler combination can be helpful to reduce the environmental impact. Rotor spinning has lower environmental impact compared to ring spinning. Increase in the rotor speed (a challenging task), efficient driving system, improved design of rotor surface, opening roller, navel and other spinning elements can help to reduce the environmental impact. The newest spinning technology, air jet spinning can produce yarns at the highest speed. However, the energy consumption is higher compared to rotor spinning. In addition to the speed, the other advantages of air jet spinning is the lower space needed compared to ring spinning. The reduced space needs less climatic control, hence, air jet spinning has the lowest environmental impact among the three major spinning systems.

Similar to yarn manufacturing, fabric production is also an energy intensive process. The total electrical energy consumed per linear metre of fabric (including production and consumer use) is $0.45-0.55 \mathrm{kWh}$, whereas the thermal energy per linear metre of fabric (production and consumer use) is 18.8-23 


\section{Current Trends in Fashion Technology \& Textile Engineering}

MJ [46]. From the above discussions, it is evident that energy is one of the prime factors influencing the cost; hence, energy efficient technologies can help in sustainable production. Newer weaving technologies such as projectile, rapier, air jet, waterjet and multi-phase looms consume lower energy and give better efficiency compared to the conventional weaving machineries and generate less waste.

Between the two major processes of fabric production, weaving and knitting, the former has the higher environmental impact than the latter. This can be attributed to the additional process of sizing, desizing, and warp preparation for weaving, which is not needed for knitting. The application of sizing and subsequent desizing consumes large amount of water in addition to energy. The effluent of traditional sizing is highly polluting, which is being replaced with new sizing materials such as polyvinyl alcohol (PVA) [47].

The use of seamless garment manufacturing can help to reduce the environmental impact [48]. In seamless technology the 3-dimensional garment is produced by avoiding the steps of fabric manufacturing (weaving/ knitting), cutting and sewing operations. Hence, this process consumes 30-40\% less time and saves energy compared to the conventional process. Furthermore, seamless technology reduces labour cost, lead time and eliminates waste involved in cutting of pattern pieces.

\section{Fabric Chemical Processing}

Fabric chemical processing or wet processing is the most environmentally harmful process among all the textile and garment processes as it uses a large amount of water, energy and toxic chemicals [49-51]. Marcucci et al. [52] noted that the production of $1 \mathrm{~kg}$ of processed fabric consumes about 200$400 \mathrm{~L}$ of water, which generates substantial amount of effluent. Water pollution produced by the textile industries is a major concern in many developing countries [53,54]. In addition to the pollution, the demand for water usage is ever-increasing due to increased volume to textile and clothing production. In many countries such as China, there is acute shortage of clean water. Hence, the direct discharge of the effluents into water systems is aggravating the scarcity of clean water.

Table 2: List of some commonly used toxic chemicals in chemical processing [12].

\begin{tabular}{|c|c|}
\hline $\begin{array}{c}\text { Name of toxic chem- } \\
\text { ical }\end{array}$ & Used as/in \\
\hline $\begin{array}{c}\text { Tributyltin oxide } \\
\text { (TBTO) }\end{array}$ & Biocide used on hosiery and fabrics \\
\hline Non-ionic surfactants & Detergents in textile preparation and dyeing \\
\hline Cationic surfactants & Textile dyeing and finishing \\
\hline Sodium chloride & Dyeing of cotton textiles \\
\hline Sodium sulphate & Dyeing of cotton textiles \\
\hline Copper & $\begin{array}{c}\text { Dyeing of cotton and polyamide; in its ele- } \\
\text { mental, non-complexed form, it is toxic }\end{array}$ \\
\hline Cyanide & Anti-caking agent in salt \\
\hline
\end{tabular}

Conventional wet processes such as scouring, bleaching, dyeing and printing consumes large amount of water and results in a substantial amount of effluent. About 2000 different chemicals are used in textile wet processes, which is about $27 \%$ of the global chemical production [55]. Many of these chemicals are harmful to the environment as well as human health. Textile effluents contain contaminants such as dyes, surfactants, solvents, heavy metals, inorganic salts, enzymes, oxidising and reducing agents, as listed in Table 2 . Several chemicals listed in Table 2 are banned in many countries, based on the global legislation governing the use of toxic chemicals in fashion production. Approaches such as use of safe chemicals, reduced chemical usage, use of ecofriendly processes, use of enzymes and biotechnology can help in sustainable fashion production, which is highlighted in the following section.

\section{Ecofriendly Chemical Processing}

The effluent created in wet processing contains toxic organic materials as discussed in Table 2, which are non-biodegradable and difficult to separate during effluent treatment. Therefore, newer technologies and nontoxic chemicals (dyes, auxiliaries and surfactants) should be used to reduce the environmental load. These newer approaches should focus on use of alternative advanced techniques or combined processes, new chemical formulations, reuse of dye-bath, waste reduction, and effluent treatment. Several researches have been done to save energy, reduce consumption of water and hence, the effluent by adapting alternative greener technologies [56,57].

Khatri et al. [58] reviewed developments in the dyeing of cotton fabrics with reactive dyes to reduce effluent pollution. It was suggested that focusing on the use of alternative dyeing techniques can substantially reduce the effluent. As effluent treatment requires additional capital investment, high cost of effluent treatment and maintenance, textile plants should focus on adapting newer technologies. Approaches such as use of advanced processes with recent dyestuffs and modern dyeing machinery, can help to reduce environmental concern. Some of the processes include: low liquor-to-material ratio dyeing, low padding trough volumes, pad dyeing technology, urea and salt-free continuous dyeing, modified washing-off techniques, micelle dyeing, polymerisation techniques for dye fixation, use of biodegradable organic compounds as dye liquor, and use of chemically modified cotton materials prior to dyeing. Khatri et al. [57] also showed that the integrated approach of desizing, bleaching and reactive dyeing can result in reduced cost due to reduced use of chemicals and energy.

As mentioned earlier, fabric chemical processing consumes large amount of water, which necessitates drying at the end of the process using thermal energy. Hence, alternative water-free techniques can reduce the consumption of water and thermal energy. For example, plasma treatment is a dry and ecofriendly technology that can help to achieve new functionalities, such as hydrophilicity, water repellency, anti-static effect, increased 


\section{Current Trends in Fashion Technology \& Textile Engineering}

dyeabilty and antibacterial properties, without altering bulk properties and aesthetics of fabrics [59-63]. Plasma treatment is performed by exciting partially ionised gas with the consumption of low amount of water and energy. Although, plasma technology is an ecofriendly process that avoids generation of effluents, the economic aspects of textile application need to be assessed before adopting the technology.

Thermal processes such as extrusion coating [64] can be applied to textiles for achieving various functionalities such as flame retardancy, hydrophobicity and antibacterial properties. Radiation curing process that use light-emitting diode (LED) or ultra-violet (UV) or electron-beam can be used to reduce the energy consumption to achieve flame retardancy, improved abrasion resistance and hydrophobicity [65]. Digital printing can be used for the colouration or printing of textiles with minimal or no use of water and solvents [66,67].

Research interest is increasing on Layered Double Hydroxide (LDH) to achieve various functionalities in textiles for developing nano-hybrids [68]. LDHs are environmentally benign, that can be applied to textiles, biotechnology, pharmaceuticals, filtration, and scavenging electroactive and photoactive materials. In a recent publication Barik et al. [68] showed that the application of Mg-Al nano-LDH with reactive remazol dye helped to improve UV protection and enhanced flame retardation, with significantly increased tensile strength of cotton fabric.

The application of enzymes in chemical processing is ever increasing, due to their ability to replace the harsh chemicals, and the reduction of water, energy and chemical usage $[69,70]$. Chemical processes using enzymes operate at lower temperature and neutral $\mathrm{pH}$, which can help in reduced energy consumption and lowers effluent in several applications. For example, in cotton garment production, enzymes can be used in desizing, scouring, bleaching, and stone-washing of denim to create a fashionable appearance. Furthermore, enzymes can also be used in bio-finishing, to remove pills and fuzz (to improve surface appearance), laundering of garments and stain removal applications. Enzymes such as Cellulases, Amylases, Pectinases, Proteases, Glucose Oxidase, Catalases, Laccases, Peroxidases, and Tyrosinases are used in various chemical processing [71].

Other greener processes for textile colouration include use of ionic liquids, supercritical carbon dioxide, mass colouration and natural dyeing. Applications such as nano-finishing, sol-gel coating and bio-finishing is also getting increased attention in textile industries. Technologies such as Dye Coo (incorporating powder dye into polyester fabric using $\mathrm{CO} 2$, which is water free process, reduces energy and chemical consumption by $50 \%$ compared with conventional methods and Air Dye (direct transfer of dye into polyester fabric from paper using printing machines, which uses reduced water and energy, and has lower greenhouse gas emissions) can be applied to reduce water and energy consumption, and reduce the generation of effluents.

\section{Effluent Treatment}

Generally, the effluent generated during chemical processing is treated by different techniques before discharged to the water systems. Conventional effluent treatment techniques such as UV treatment [72], Ozonisation [73], hydrogen peroxide treatment [74,75], TiO2 photocatalysis [76], Fenton's reagent [77] and electrochemical processes [78] are found to be inadequate in effluent treatment, as the new classes of dyestuffs and auxiliaries can resist these processes [79-81]. Hence, advanced techniques such as chemical precipitation [82], biological treatment [83-85], activated carbon adsorption [86], membrane technology [87], ultrafiltration [52,88], microfiltration [87], nano-filtration [8991], reverse osmosis [92,93], coagulation-membrane separation [94], and evaporation [95] are being widely adopted by textile manufacturers.

The application of membrane-based processes (filtration) for effluent treatment is becoming popular due to their high removal efficiency, as well as reusability of water and other constituents [96]. For recycling of insoluble dyes (such as disperse or Indigo), auxiliary chemicals (polyvinyl alcohol) and water, the ultrafiltration process is becoming popular $[88,97]$. Filtration processes may need high initial outlay, but the process can be economical due to high efficiency of extracting reusable salt, permeate, and water. The other drawbacks of the filtration process are the disposal of concentrate stream, which is done by incineration, evaporation or discharging it into the ocean. These processes are not environmental friendly. The combination of a biological reactor and membrane separation device, commonly known as membrane bioreactor (MBR), is a new innovative concept for effluent treatment $[98,99]$.

\section{Garment Manufacturing}

Garment manufacturing process is energy intensive and there are a wide range of areas garment manufacturers can focus to reduce the energy usage [100]. The use of energy efficient tools, equipment and machinery for cutting, sewing, pressing and packaging; and the use of ecofriendly processes are the key factors requiring improvement to produce sustainable fashion [9]. The waste generated during garment production such as paper, plastic, fabric remnants, cardboards used for packaging, and wire coat hangers should be recycled and reused. Several other strategies for saving energy and water, such as installing water efficient fixtures, training the staffs on energy efficiency skillsets, energy efficient heating/cooling devices, sensorenabled lighting systems, and rain-water harvesting for nondrinking purposes can also help in achieving sustainable fashion.

The production process of a garment industry follows the steps as shown in Figure 1 [101]. The dotted and solid lines show the material and process flows, respectively. The selection of appropriate raw materials with a lower ecological footprint (renewable, biodegradable and non-depleting) and energy efficient processes can help to reduce the environmental impact. 
The factors related to sustainability in fashion products are marked inside the red rectangle. Use of renewable energy, energy saving wherever possible, reducing air pollution, recycling hard waste, and giving attention to social accountability can help in achieving sustainability in fashion Figure 1.

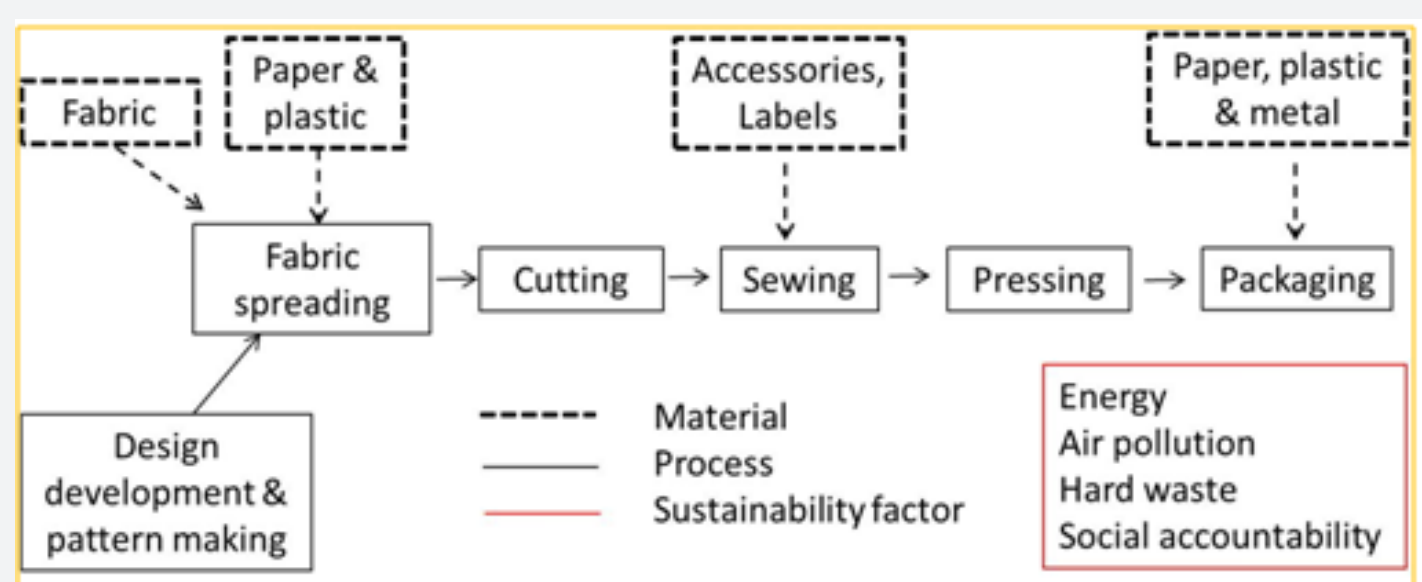

Figure 1: Flow chart for the material and process flow, and sustainable factors in garment manufacturing.

The operational costs in garment production can be reduced by adopting the concept of "Lean manufacturing", which focuses on eliminating the process waste, improving productivity, empowering people with greater communication, and converting the organisation into a learning organisation [102]. The process waste can be reduced by avoiding over production, unnecessary motion, improper inventory management, and over processing. Continual improvement (generally known as the Japanese word 'Kaizen') is the major principle of lean manufacturing. 'Kaizen' promotes continuous and necessary changes (big or small) towards the achievement of a desired goal.

The fundamental thrust of lean manufacturing is to produce a high quality product at lower cost by reducing or eliminating the seven cardinal wastes such waiting, inventory, overproduction, repair, inappropriate processing, excess motion, and transportation from the value stream through continuous improvement and to deliver the value to the customer [103]. The goal of the lean manufacturing is to create an integrated system using multi-dimensional approach that includes adoption of management practices such as pull strategy, just in time philosophy, total quality management, cellular manufacturing, Electronic data interchange (EDI), Kanban and co-design. Lean production techniques create a sustainable and positive work environment by emphasising on empowering the workers and adopting the tools which enhance the operational efficiency by cycle reduction, cellular manufacturing, working in teams and stabilizing work flow etc. Yang et al [104] adds that when the different forms of wastes in lean culture are reduced, will in turn useful in managing the environmental waste by enhancing environmental performance

Herva et al. [105] developed a useful tool to evaluate the influence of a garment manufacturing plant's environmental impact. They analysed the ecological footprint (EF) and compared the data to examine the environmental impact of different processes in a garment manufacturing plant. The authors collected data and divided the data into three categories: energy, resources, and waste. The major contributor to the final EF was obtained from the resources category (91.33\%), as materials constitute the primary factors in garment manufacturing. Energy consumption was the second contributor accounting for $5.32 \%$, while the waste category was the lowest at $3.35 \%$.

\section{Eco-Labelling}

The Global Eco-labelling Network defines an eco-label as "a label which identifies overall environmental preference of a product within a product category based on life cycle consideration" [106]. Eco-labels provide information on ecofriendly products to consumers, which can help in reducing the environmental impacts on their daily activities. Consumers can compare various products in manufactured using ecofriendly processes, so they are informed about the adverse consequences during use and disposal. Eco-labelling has an important role in the development of sustainable fashion products globally, and it differentiates retail markets for "go green" customers. Neutral third parties are involved in awarding the eco-label to the products that fulfil the established environmental criteria. The major goals of eco-labelling are [107]:
a. Creating awareness on ecofriendly products
b. Improving environmental protection
c. Assuring enterprises contribute towards improved environmental safety and social impacts

d. Performing an educational role with a seal of ecological approval

e. Increasing transparency within the international market 


\section{Current Trends in Fashion Technology \& Textile Engineering}

f. Promoting "green innovation" and "entrepreneurship" resulting in higher future value
The eco-labels may be categorised into governmental and commercial, which can vary in different countries. Various categories of eco-labels are listed in Table 3 [35].

Table 3: Various categories of eco-labels [35].

\begin{tabular}{|c|c|c|}
\hline \multirow{4}{*}{ Category } & Name of the eco-label & Country \\
\hline \multirow{4}{*}{ Governmental } & Blue Angel & Germany \\
\cline { 2 - 3 } & Green Seal & USA Japan, India \\
\cline { 2 - 3 } & Eco-mark & EU \\
\cline { 2 - 3 } & European Flower & France \\
\hline \multirow{2}{*}{ Commercial } & NF Environment & Austria/Germany \\
\cline { 2 - 3 } & Oeko-Tex Standard 100 & Germany (carpet) \\
\cline { 2 - 3 } & GuT & Germany (furnishing) \\
\cline { 2 - 3 } & GuW & Global Organic Textile Standard \\
\cline { 2 - 3 }
\end{tabular}

\section{Product Life Cycle Assessment}

Global environmental challenges and climatic changes have necessitated the integration of environmental considerations into individuals, businesses, policy makers, and public administrations [108]. Tools and indices are being developed for assessing and benchmarking the impact of various systems on the environment, which include Life Cycle Assessment (LCA), Environmental Impact Assessment (EIA), Strategic Environmental Assessment (SEA), Cost-Benefit Analysis (CBA), Environmental Risk Assessment (ERA), Material Flow Analysis (MFA) and Ecological Footprint $[109,110]$. Among these, LCA is widely used for fashion and textile products.

LCA is a systematic approach used to estimate the environmental impact of a product from cradle to grave (from raw material procurement, production and use phase, to the waste management stage) [111]. The design and development phase of the product is not involved in LCA, although these stages can greatly influence the other stages of LCA [112]. In the LCA process, the impact of the product on human health, the natural environment, and resources is measured during each stage of product manufacture [111].

A schematic of the fashion and textile production from cradle to grave is shown in Figure 2. The major participants in fashion production include fibre producers, yarn and fabric manufacturers, fashion manufacturers, retailers, and finally the consumers. For an accurate LCA, environmental data and process inputs and outputs need to be collected from each of these participants. However, the complexities involved in getting information lead to lack of transparency in manufacturing and potential negative environmental impacts.

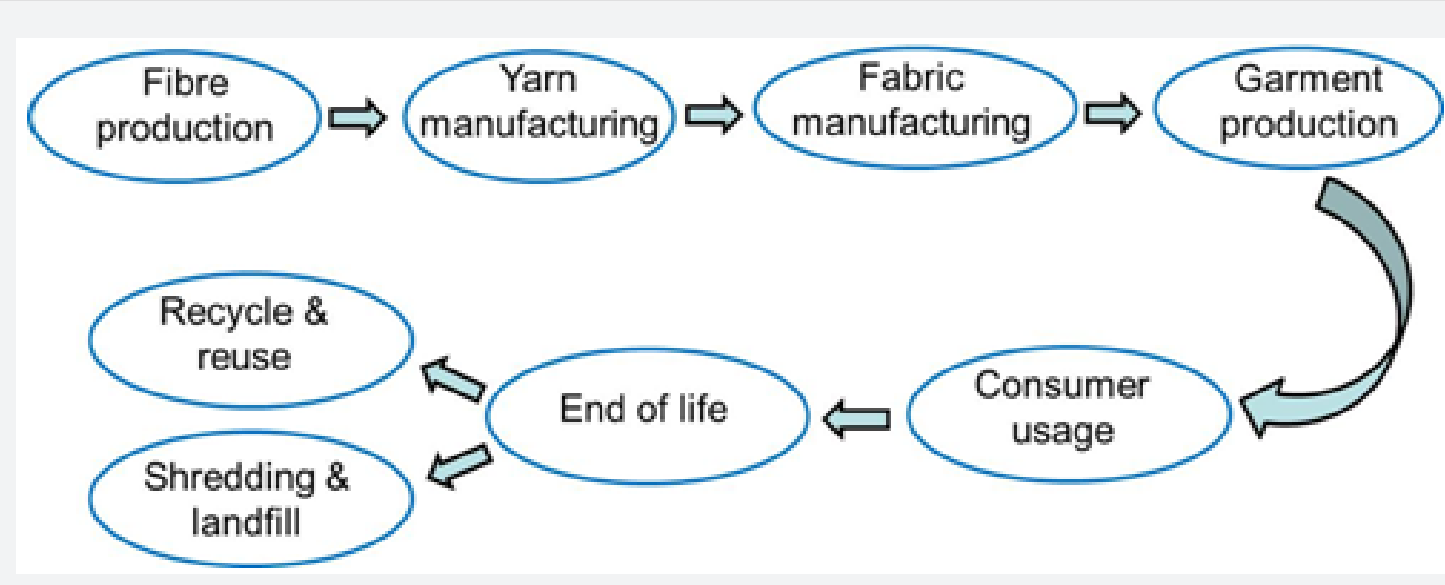

Figure 2: Production process of fashion and textile materials.

Fashion products should be manufactured with the objective that they are serviceable for a sufficient amount of time and recyclable so that they are not used in landfill at the EOL.
Extending the overall service life of apparel can reduce the environmental load. Approaches such as: 
1) Manufacturing products with extended durability or reconfigurable garments so that their durability is extended in the first life,

2) Manufacturing reusable garments,

3) Making garments reusable after their first life, and

4) Selecting fibres witheasy recyclability for manufacturing the garment; can help to address sustainability issues.

\section{Recyclability}

As discussed previously, fast fashion items are disposed of more frequently, and this has become a relatively new area of research [113]. Consumers should be aware of the concepts of reuse or recycle while discarding fast fashion items. Producers and retailers should encourage consumers to purchase environmentally sustainable products and recycle waste. Three major factors such as: intrinsic factors (related to the product style, age, condition, value, cost and durability); psychological factors (related to decision-making), which involves attitude, personality and social conscience; and situational factors (extrinsically related to the product such as fashion changes, finances and storage space) which explains the "disposal" behaviour of the consumers and places them as "redistributors" in the fashion chain, as opposed to "end-users" [114]. Burke et al. [115] surveyed consumer's responses towards discarding a product and observed that young consumers pay little attention to reuse or recycle while disposing.

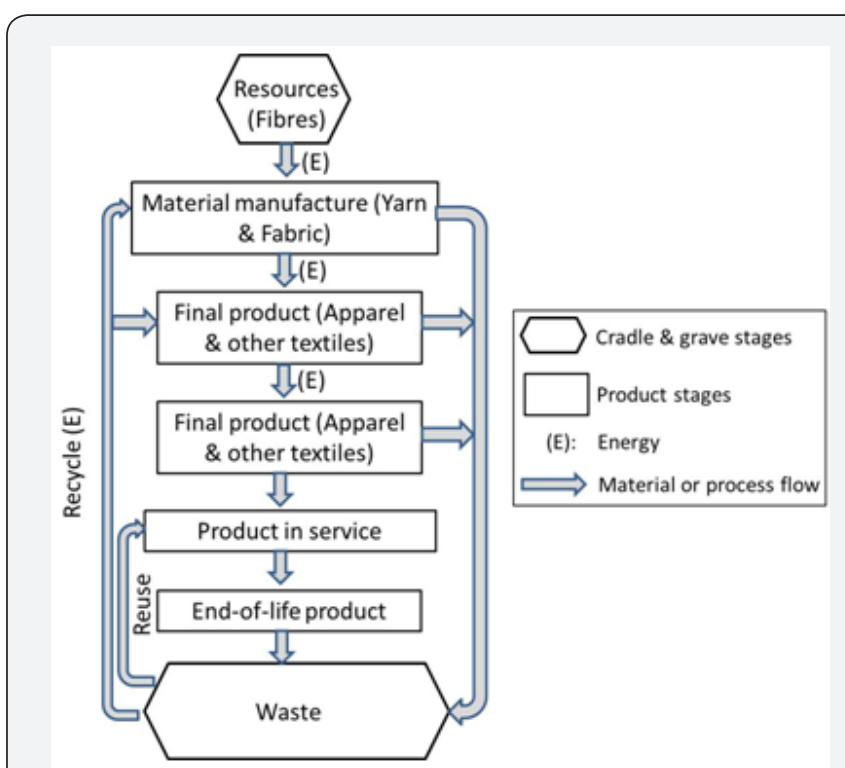

Figure 3: Various sustainability factors associated with a fashion production.

Fashion items become unusable after certain time-frame, resulting in an EOL product. In the past, EOL products were disposed to get rid of them, or they were used for second hand clothing, wiping cloths, or for fibre reclamation. As the importance of sustainability is increasing, sustainable solutions such as recycle, or reuse are needed to reduce negative environmental impacts and reduce the resource consumption. This will also help in the reduction of pollution levels and energy consumption. Various sustainability factors associated with a fashion production are shown in Figure 3.

Energy is consumed from the fibre to the finished garment stage, waste is generated, and the product then needs to be transported to the point of sale, which should be addressed by sustainable approaches. Furthermore, at the EOL, the fashion and textile products can be dumped as landfill, reused as secondhand clothing or recycled. The option of reusing or recycling seems to be more sustainable compared to landfill.

As the world is becoming more environmentally conscious, it is appropriate that all fashion items are recyclable. The recent legislative regulations in many countries do not allow landfilling of EOL fashion products. Associations such as United Nation (in UN's Environment Program (UNEP)), the European Commission (in the European Platform for LCA), the Society of Environmental Toxicology and Chemistry (SETAC) and the Recycling Consortium (TRC) are facilitating research to use recyclable materials and to design for ease of disassembly. Table 4 shows the recycling possibilities of EOL fashion products Table 4.

Table 4: Various recycling possibilities for EOL fashion products.

\begin{tabular}{|c|c|c|c|}
\hline $\begin{array}{c}\text { Sustainability prac- } \\
\text { tises }\end{array}$ & Process & $\begin{array}{c}\text { Areas of } \\
\text { application }\end{array}$ & Comments \\
\hline Reuse & $\begin{array}{l}\text { Sorting, } \\
\text { laundering, } \\
\text { ironing, } \\
\text { packaging } \\
\text { \& display }\end{array}$ & $\begin{array}{l}\text { Second hand } \\
\text { apparels }\end{array}$ & $\begin{array}{l}\text { Reduced/no } \\
\text { waste } \\
\text { Low energy } \\
\text { consumption }\end{array}$ \\
\hline $\begin{array}{l}\text { Recycle (to reusable } \\
\text { product) }\end{array}$ & $\begin{array}{l}\text { Sorting, } \\
\text { rework, } \\
\text { laundering, } \\
\text { ironing, } \\
\text { packaging } \\
\text { \& display }\end{array}$ & $\begin{array}{l}\text { Second hand } \\
\text { apparels }\end{array}$ & $\begin{array}{l}\text { Reduced/no } \\
\text { waste } \\
\text { Low energy } \\
\text { consumption }\end{array}$ \\
\hline $\begin{array}{l}\text { Recycle (to new } \\
\text { product) }\end{array}$ & $\begin{array}{l}\text { The fibres/ } \\
\text { yarns are } \\
\text { extracted } \\
\text { from the } \\
\text { fabric and } \\
\text { used o } \\
\text { different } \\
\text { products }\end{array}$ & $\begin{array}{l}\text { Cleaning or } \\
\text { wiping cloths, } \\
\text { filling mate- } \\
\text { rials in some } \\
\text { low-cost } \\
\text { mattresses }\end{array}$ & $\begin{array}{l}\text { Reduced/no } \\
\text { waste } \\
\text { Low energy } \\
\text { consumption }\end{array}$ \\
\hline $\begin{array}{l}\text { Fibre extraction } \\
\text { (Thermoplastics) }\end{array}$ & $\begin{array}{l}\text { Depo- } \\
\text { lymeri- } \\
\text { sation of } \\
\text { fibres to } \\
\text { obtain raw } \\
\text { polymer }\end{array}$ & $\begin{array}{l}\text { Can be used } \\
\text { to produce } \\
\text { textiles with } \\
\text { low quality } \\
\text { requirements }\end{array}$ & $\begin{array}{l}\text { High waste } \\
\text { generated } \\
\text { Highest energy } \\
\text { consumption }\end{array}$ \\
\hline Landfill & $\begin{array}{l}\text { Dumping } \\
\text { into the } \\
\text { landfill } \\
\text { sites }\end{array}$ & Landfilling & $\begin{array}{l}\text { Highest waste } \\
\text { generated }\end{array}$ \\
\hline
\end{tabular}


Fashion wastes can be classified as consumer waste and industrial waste. The recycling of consumer waste (EOL apparels) is rather difficult as it consists of materials of unknown fibre mixture, and non-fibrous materials such as zippers, buttons and other metal parts. However, the recycling of industrial waste is easier. Hence, the option of "reuse" of consumer waste is the appropriate method; this involves inspection, cleaning, ironing and packing. The EOL fashion items that cannot be reused can be used as wiping or cleaning cloths, flocks for nonwovens, bondawaste, and for the paper and cardboard industry.

\section{Corporate Social Responsibility}

Sustainable practises of the 21st Century often involve corporate social responsibility (CSR) or social accountability $[116,117]$. In addition to managing the environment, sustainability also focuses on relationships between manufacturers, retailers, communities, and other institutions. CSR is based on the essential principles of sustainable practises for fashion manufacturers and retailers that affect human well-being. Some fashion brands are being rated in terms of their social accountability and the value they offer to society $[118,119]$. The fragmented fashion production and inherently complex processes makes it difficult to adopt the sustainable practices of CSR in fashion production compared with the others.

The workforce involved in fashion production can be classified as homeworkers, contract labour, migrant labour, and permanent employees. In several instances, the garment workers are informally employed and work from home, which is rarely included in national statistics [120]. These workforces primarily constitute women (about $90 \%$ of the total workforce), who are involved in the stitching of women's and children's wear [120]. When there is a demand for higher technical skills to operate specialised tools and equipment, men are given priority, which narrows learning opportunities for women [121].

The garment workforce (homeworkers and contract labours) are paid at "piece rate" (the number of garments they produce) and do not receive any overtime wages, which leads to low pay. Several workers don't receive any sick leave, personal leave, or even maternity leave. In addition to the low piece rates, the homeworkers face other exploitation. For example, homeworkers have to cover all the costs of production, such as managing the workplace, lighting, equipment, and electricity. They are not paid regularly, and in some cases, they have to wait for months for their wages. During the global economic crisis, many fashion producers in Asian countries further reduce the piece-rate wages, reduce working time and delay the payments [122]. The other challenges the homeworkers face is loadshedding, increased electricity charges, inadequate working space in the house, transport charges (to collect raw materials and deliver the final product) and storage problems.

The garment workforce is subjected to health risks such as eye-strain, exhaustion, dust from cloth pieces, muscular pain and exposure to smells from hazardous chemicals (dyes, pigments and finishes) [123]. Informal workers in garment and textile units often experience isolation and lack of power. They are subjected to long working hours $(10-12 \mathrm{~h} /$ day or even $18 \mathrm{~h} /$ day close to the deadline for a consignment). Some of the fashion manufacturers make overtime mandatory, and the workers who cannot meet these conditions are subjected to verbal abuse, or face penalties, or are even dismissed from work.

In addition, the working conditions in many production units are poor and lack the basic amenities such as availability of clean drinking water, good sanitary facilities, a well illuminated and ventilated working area, well managed waste disposal system, first aid facilities, and fire extinguishers. The fashion manufacturing buildings are ill-equipped with emergency exits, lack people with basic firefighting skills, and don't provide the required safety devices and protective clothing to the workers. The deadliest disaster in the history of global garment industry was the collapse of the Rana Plaza building in Bangladesh in 2013, where more than 1,100 workers involved with highstreet retailers in the west died [124]. This disaster brought global attention to the booming fashion industry, resulting in manufacturers, retailers and the Bangladesh Government promising widespread reforms. Western retailers' aftermath of the incident, emphasised high work standards in the industry. However, it is not always feasible to monitor the problem, as massive sub-contracting is involved in the manufacturing process. Although thousands of factories are being inspected for structural integrity, and many of them closed or refurbished, the problems still exist [125]. Continuous effort by the manufacturers and retailers in addition to stricter regulations can help to alleviate this problem.

Due to stiff global competition, fashion brands recently are giving increased attention to social accountability within their organisations and adopting sustainability practises to keep their brand names reputable [126]. The focus of these firms on social well-being is helping to achieve improved labour standards, enhancing communities, and generating socially responsible products and services [127]. Yang et al. [104] suggested that sustainability helps to achieve social goals as well as provides competitive advantages for corporate survival. Customers can also help by taking into consideration while buying, the social cost of factory employees working under strenuous conditions and acute poverty.

\section{Economic Sustainability}

Economic sustainability in fashion ensures that the business is achieving its targeted profitability, simultaneously using the resources in a sustainable manner (i.e. the business is not creating environmental concerns or using excessive resources). There is a steadily increasing trend in the number of firms considering their relationship to the community, in order to improve the economic sustainability. Manufacturing of fashion products in a country to be sold locally or globally has direct or 


\section{Current Trends in Fashion Technology \& Textile Engineering}

indirect influence on that country's economy. The sustainability practises in fashion should not ignore the dilemma of resource depletion [46]. Economists are now concerned the rate at which the resources are being used to fulfil human needs. Economic models are being developed that account for resource depletion, non-renewability of natural resources and economic development. If the resources are used indiscriminately at an ever-growing rate, one day some of the resources may fall or be in short supply or be completely exhausted. This will create a negative impact on the economic growth. Hence, economic theories need to establish focusing on the long-term growth and progress in a limited resources era. Alternative resources should be used to meet consumer demands to avoid the depletion of the resources and keep the economic growth sustainable. Other aspects of economic sustainability include "sustainable procurement", which is a smart approach to manage the budget, where all the purchases including office supplies to energy providers are managed sustainably to maximize the social, environmental and economic impacts. Sustainable procurement has a direct impact on the profitability of the firm as well as the life standards of the workers. A new ISO standard "ISO/DIS 20400.2" has been developed to help organisations

Table 5: List of organisations working on global sustainability issues.

\begin{tabular}{|c|c|}
\hline Organisation & Major work \\
\hline United Nations Environment Programme (UNEP) & $\begin{array}{l}\text { UNEP assists developing countries in environmental activities to imple- } \\
\text { ment environmentally sound policies and practices. }\end{array}$ \\
\hline United Nations Economic and Social Council (ECOSOC) & $\begin{array}{l}\text { ECOSOC (one of the six principal organisations of the UN) coordinates } \\
\text { the economic, social and related work of } 15 \text { UN specialised agencies, } \\
\text { their functional commissions and five regional commissions. }\end{array}$ \\
\hline Consumers International (CI) & $\begin{array}{l}\text { CI works on awareness of consumer rights and responsibilities based on } \\
\text { the changes in government policy and corporate behaviour. }\end{array}$ \\
\hline Organization for Economic Cooperation and Development (OECD) & $\begin{array}{c}\text { OECD promotes economic growth, prosperity, and sustainable develop- } \\
\text { ments. There are } 34 \text { democracies working together and more than } 70 \\
\text { non-member countries. }\end{array}$ \\
\hline Friends of the Earth International (FoEI) & $\begin{array}{l}\text { FoEI is an international network of environmental organisations work- } \\
\text { ing on environmental issues in their social, political and human rights } \\
\text { contexts. }\end{array}$ \\
\hline Intergovernmental Panel on Climate Change (IPCC) & $\begin{array}{l}\text { IPCC produces reports on the basis of the agreement of leading climate } \\
\text { scientists and the consensus of participating governments that provides } \\
\text { an internationally accepted authority on climate change. }\end{array}$ \\
\hline International Labour Organization (ILO) & $\begin{array}{c}\text { ILO works to promote living standards, improve working conditions, fair } \\
\text { wages and adequate employment opportunities. It also publishes its own } \\
\text { research on social and labour matters. }\end{array}$ \\
\hline International Union for Conservation of Nature (IUCN) & $\begin{array}{l}\text { IUCN is an international organisation working for nature conservation } \\
\text { and sustainable use of natural resources. }\end{array}$ \\
\hline Greenpeace International & $\begin{array}{c}\text { Greenpeace International works on the use of resources and clean } \\
\text { energy. }\end{array}$ \\
\hline International Solar Energy Society (ISES) & $\begin{array}{l}\text { ISES is a global organisation working on the development and utilisation } \\
\text { of renewable energy. }\end{array}$ \\
\hline International Council for Local Environmental Initiatives (ICLEI) & $\begin{array}{l}\text { ICLEI is an international association of local governments, national and } \\
\text { regional local government organisations that works towards sustainable } \\
\text { development. }\end{array}$ \\
\hline International Confederation of Free Trade Unions (ICFTU) & ICFTU works for workers' rights. \\
\hline
\end{tabular}

regarding sustainable procurement while maintaining economic

\section{Role Players}

As the importance of sustainable fashion and textile production is rapidly increasing, there are several roles that need to be accomplished by governing organisations related to sustainability, manufacturers, retailers, and finally the consumers. This is described in the following section.

\section{Role of Governing Organisations}

Several international government organisations, nongovernmental organisations (NGOs), and private firms have been developed in the last decade or so to monitor, assist and evaluate the performance of manufacturers and retailers in sustainability. The United Nations (UN) has established several organisations under its control to work independently, or in association with other organisations to achieve sustainability targets. The list of organisations working on global sustainable issues is provided in Table 5. These organisations work on the issues related to sustainability legislation such as licensing, permits, compliance requirements in managing waste, energy and water in various businesses, including fashion. sustainability. 


\section{Current Trends in Fashion Technology \& Textile Engineering}

\begin{tabular}{|c|c|}
\hline Water Environment Federation (WEF) & $\begin{array}{c}\text { WEF an organisation of engineers and industry related to water, waste- } \\
\text { water and water reuse. }\end{array}$ \\
\hline World Watch Institute (WWI) & $\begin{array}{c}\text { WWI is an independent research institute focusing on global environ- } \\
\text { mental problems and assists in rapid transition to sustainable develop- } \\
\text { ment. }\end{array}$ \\
\hline Social Accountability Accreditation Services (SAAS) & $\begin{array}{c}\text { SAAS assists in social responsibility and accountability by ensuring the } \\
\text { implementation of credible systems designed to protect people and their } \\
\text { communities. }\end{array}$ \\
\hline
\end{tabular}

\section{Role of Standards}

Several standards have been developed to provide guidelines supporting the three pillars of sustainability. The leading role is played by the International Standards Organisation (ISO). A series of standards have been developed; for example, ISO
14000 series on EMS and practises. ISO 14000 series provides information and practical tools to the manufacturers and retailers to manage their environmental responsibilities. Some of the important ISO standards related to sustainability are listed in Table 6.

Table 6: List of ISO Standards related to sustainability.

\begin{tabular}{|c|c|}
\hline Standards & Description \\
\hline ISO/TC 207 & Environmental management (EM) \\
\hline ISO 14001:2015 & $\begin{array}{l}\text { Environmental management system (EMS)-- Requirements with guid- } \\
\text { ance for use }\end{array}$ \\
\hline ISO $14004: 2016$ & EMS-- General guidelines on implementation \\
\hline ISO $14005: 2010$ & $\begin{array}{l}\text { EMS-- Guidelines for the phased implementation of an environmental } \\
\text { management system, including the use of environmental performance } \\
\text { evaluation }\end{array}$ \\
\hline ISO $14006: 2011$ & EMS-- Guidelines for incorporating eco-design \\
\hline ISO $14015: 2001$ & $\begin{array}{l}\text { Environmental management -- Environmental assessment of sites and } \\
\text { organizations (EASO) }\end{array}$ \\
\hline ISO $14020: 2000$ & Environmental labels and declarations -- General principles \\
\hline ISO 14021:2016 & $\begin{array}{l}\text { Environmental labels and declarations -- Self-declared environmental } \\
\text { claims (Type II environmental labelling) }\end{array}$ \\
\hline ISO 14022:2009 & $\begin{array}{l}\text { Environmental Labels and Declarations: Self-Declaration Environmental } \\
\text { Claims, Symbols }\end{array}$ \\
\hline ISO 14023:2009 & $\begin{array}{l}\text { Environmental Labels and Declarations: Self-Declaration Environmental } \\
\text { Claims, Testing and Verification }\end{array}$ \\
\hline ISO 14024:1999 & $\begin{array}{l}\text { Environmental labels and declarations -- Type I environmental labelling } \\
\text {-- Principles and procedures }\end{array}$ \\
\hline ISO $14025: 2006$ & $\begin{array}{l}\text { Environmental labels and declarations -- Type III environmental declara- } \\
\text { tions -- Principles and procedures }\end{array}$ \\
\hline ISO 14031:2013 & EM -- Environmental performance evaluation -- Guidelines \\
\hline ISO/TS 14033:2012 & $\begin{array}{l}\text { EM -- Quantitative environmental information -- Guidelines and exam- } \\
\text { ples }\end{array}$ \\
\hline ISO $14034: 2016$ & EM -- Environmental technology verification (ETV) \\
\hline ISO 14040:2006 & EM -- Life cycle assessment -- Principles and framework \\
\hline ISO $14044: 2006$ & EM -- Life cycle assessment -- Requirements and guidelines \\
\hline ISO $14045: 2012$ & $\begin{array}{l}\text { EM -- Eco-efficiency assessment of product systems -- Principles, re- } \\
\text { quirements and guidelines }\end{array}$ \\
\hline ISO $14046: 2014$ & EM -- Water footprint -- Principles, requirements and guidelines \\
\hline ISO/TR 14047:2012 & $\begin{array}{l}\text { EM -- Life cycle assessment -- Illustrative examples on how to apply ISO } \\
\qquad 14044 \text { to impact assessment situations }\end{array}$ \\
\hline ISO/TS 14048:2002 & EM -- Life cycle assessment -- Data documentation format \\
\hline ISO/TR 14049:2012 & $\begin{array}{l}\text { EM -- Life cycle assessment -- Illustrative examples on how to apply ISO } \\
14044 \text { to goal and scope definition and inventory analysis }\end{array}$ \\
\hline
\end{tabular}




\section{Current Trends in Fashion Technology \& Textile Engineering}

\begin{tabular}{|c|c|}
\hline ISO 14051:2011 & EM -- Material flow cost accounting -- General framework \\
\hline ISO/TR 14062:2002 & $\begin{array}{l}\text { EM -- Integrating environmental aspects into product design and devel- } \\
\text { opment }\end{array}$ \\
\hline ISO 14063:2006 & EM -- Environmental communication -- Guidelines and examples \\
\hline ISO 14064-1:2006 & $\begin{array}{l}\text { Greenhouse gases -- Part 1: Specification with guidance at the organiza- } \\
\text { tion level for quantification and reporting of greenhouse gas emissions } \\
\text { and removals }\end{array}$ \\
\hline ISO $14064-2: 2006$ & $\begin{array}{l}\text { Greenhouse gases -- Part 2: Specification with guidance at the project } \\
\text { level for quantification, monitoring and reporting of greenhouse gas } \\
\text { emission reductions or removal enhancements }\end{array}$ \\
\hline ISO 14064-3:2006 & $\begin{array}{c}\text { Greenhouse gases -- Part 3: Specification with guidance for the valida- } \\
\text { tion and verification of greenhouse gas assertions }\end{array}$ \\
\hline ISO $14065: 2013$ & $\begin{array}{l}\text { Greenhouse gases -- Requirements for greenhouse gas validation and } \\
\text { verification bodies for use in accreditation or other forms of recognition }\end{array}$ \\
\hline ISO $14066: 2011$ & $\begin{array}{l}\text { Greenhouse gases -- Competence requirements for greenhouse gas vali- } \\
\text { dation teams and verification teams }\end{array}$ \\
\hline ISO/TS 14067:2013 & $\begin{array}{l}\text { Greenhouse gases -- Carbon footprint of products -- Requirements and } \\
\text { guidelines for quantification and communication }\end{array}$ \\
\hline ISO/TR 14069:2013 & $\begin{array}{l}\text { Greenhouse gases -- Quantification and reporting of greenhouse gas } \\
\text { emissions for organizations -- Guidance for the application of ISO 14064- } \\
1\end{array}$ \\
\hline ISO/TS 14071:2014 & $\begin{array}{l}\text { EM -- Life cycle assessment -- Critical review processes and review- } \\
\text { er competencies: Additional requirements and guidelines to ISO } \\
14044: 2006\end{array}$ \\
\hline ISO/TS 14072:2014 & $\begin{array}{l}\text { EM -- Life cycle assessment -- Requirements and guidelines for organisa- } \\
\text { tional life cycle assessment }\end{array}$ \\
\hline ISO 19011:2011 & Guidelines for quality and/or EMSauditing \\
\hline ISO $26000: 2010$ & Guidance on social responsibility \\
\hline ISO/DIS 20400.2: 2016 & Sustainable procurement -- Guidance \\
\hline ISO $37101: 2016$ & Sustainable development in communities \\
\hline ISO Guide 64:2008 & Guide for addressing environmental issues in product standards \\
\hline SA8000 & $\begin{array}{l}\text { SA } 8000 \text { encourages manufacturers to develop, maintain and apply } \\
\text { socially acceptable practices in the workplace. }\end{array}$ \\
\hline
\end{tabular}

\section{Role of Manufacturers}

Fashion and textile manufacturers and retailers are the leading players in sustainable fashion production. Fashion entrepreneurs should adopt the approaches mentioned in sections 4,5 and 6 to address sustainability requirements, which will help them to satisfy the customers, stakeholders, and communities beyond the society in which they operate. Fashion brands such as Nike and Adidas are supporting ecofriendly dyeing technology to reduce waste water, chemicals, energy and toxic effluents [128]. They are introducing waterless dyeing technologies such as Dye Coo, Color Zen and Air Dye in their production. However, the cost and lack of experts in the textile industry are the hindrances to this approach. The fashion manufacturers should establish a sustainability team including designers, innovators and researchers to find new solutions for sustainable production. The current business model based on fast fashion and "just-in-time" manufacturing needs to be restructured to suit sustainability. Although restructuring is a big challenge, fashion brands and entrepreneurs must try to practise it to meet the sustainability requirements. Furthermore, the manufacturers and retailers should provide guidelines to consumers on the process of making sustainable choices and provide creative incentives for doing so. Fashion industries should organise free consumer awareness workshops to discuss on sustainable fashion, and the consumers should be provided with sustainability information at the point of sale.

International events such as the Copenhagen Fashion Summit (started in 2009, now the world's largest event on sustainability in fashion) should be organised to raise awareness of sustainability among fashion industries [129]. Leading international fashion brands participate in this event to share their knowledge and the best practices with their peers. Industries are inspired by one another to devise improved business strategies to address sustainability challenges. Transparency is also a key tool to be successful in sustainable fashion [130]. The fashion manufacturers should become more transparent, although it is hard to do so. They should provide information on the raw materials, chemicals and auxiliaries used and type of labour used, as well as product ecological footprint. 


\section{Role of Consumers}

Consumers of fashion products also play a vital role in sustainability. Consumers can select or reject a product if it is not manufactured with the right use of energy, resources or even the labour [131]. Although some consumers are ready to pay higher prices for the sustainable fashion items, many of them may not be ready due to budget limitations, choice and mindset [24]. In future, sustainable fashion will not be a reality if consumer demand does not support the corporate efforts towards sustainability. Consumers can support sustainability movement by adopting following approaches:

1) Selecting products manufactured with appropriate labour, resource consumption in socially acceptable conditions (referred to as "fair trade" products),

2) Purchasing fashion items that minimise waste, and considering the environmental impact of each product, and

3) Considering the recycle and reuse option, wherever it can be achieved, or trying to minimise the waste that goes to landfill.

\section{Conclusion}

Sustainable fashion production is gaining significant importance due to the global trend for sustainable products, and increased consumer awareness regarding sustainability. In order to reduce production costs, some fashion producers in developing countries are taking advantage of lenient regulations and low environmental awareness. However, many popular fashion brands such as H\&M, Adidas and Uniqlo are incorporating sustainable practises into their production, supply chain, and retail management. The emphasis of these brands on sustainability is helping to achieve improved labour standards which are generating socially responsible products and services and a safer environment. Several international organisations and private firms are working to monitor, assist and evaluate the performance of fashion manufacturers and retailers. These organisations work on sustainability aspects such as licensing, permits, and compliance requirements in managing waste, energy and water. Furthermore, several standards have already been developed to provide guidelines supporting the three pillars of sustainability.

In addition to the fashion producers, retailers and international organisations, the consumers play an important role in sustainable fashion. Consumers can select or reject a product if it is not manufacture with appropriate labour and resource consumption in socially acceptable conditions. Although some consumers are ready to pay higher prices for the sustainable fashion items, many of them may not be ready due to budget limitations, choice and mindset. In the future, sustainable fashion will not become a reality unless there is demand for sustainable fashion products and services. Successful consumer adoptability of sustainable fashion depends on consumer awareness through education on reducing waste and environmental impact, in addition to meeting consumer demand for ethical products. The current sustainable practises by manufacturers and retailers in the fashion industry will demonstrate how well society is ethically secured, the environment is protected, and the workforce can benefit, together with the uptake of sustainable approaches for fashion product's aftercare and disposal.

\section{References}

1. Dirty Laundry-Unravelling the corporate connections to toxic water pollution in China, Greenpeace International.

2. Aakko M, Koskennurmi Sivonen R (2013) Designing sustainable fashion: Possibilities and challenges. Research Journal of Textile and Apparel 17(1): 13-22.

3. Achabou MA, Dekhili S (2013) Luxury and sustainable development: Is there a match? Journal of Business Research 66(10): 1896-1903.

4. Aguilera RV, Rupp DE, Williams CA, Ganapathi J (2007) Putting the S back in corporate social responsibility: A multilevel theory of social change in organizations. Academy of management review 32(3): 836-863.

5. Akbari A, Remigy J, Aptel P (2002) Treatment of textile dye effluent using a polyamide-based nanofiltration membrane. Chemical Engineering and Processing: Process Intensification 41(7): 601-609.

6. Ali S, Khatri Z, Khatri A, Tanwari A (2014) Integrated desizingbleaching-reactive dyeing process for cotton towel using glucose oxidase enzyme. Journal of Cleaner Production 66: 562-567.

7. Aouni A, Fersi C, Cuartas Uribe B, Bes Pía A, Alcaina Miranda MI, et al. (2012) Reactive dyes rejection and textile effluent treatment study using ultrafiltration and nanofiltration processes. Desalination 297, 87-96.

8. Araujo R, Casal M, Cavaco Paulo A (2008) Application of enzymes for textile fibres processing. Biocatalysis and Biotransformation 26(5): 332-349.

9. Arslan I, Balcioğlu IA, Tuhkanen T (1999) Oxidative treatment of simulated dyehouse effluent by UV and near-UV light assisted Fenton's reagent. Chemosphere 39(15): 2767-2783.

10. Badani Z, Ait Amar H, Si Salah A, Brik M, Fuchs W (2005) Treatment of textile waste water by membrane bioreactor and reuse. Desalination 185(1): 411-417.

11. Baig S, Liechti $P$ (2001) Ozone treatment for bio refractory COD removal. Water Science and Technology 43(2): 197-204.

12. Bal N, Houshyar S, Gao Y, Kyratzis IL, Padhye R, et al. (2014) Digital Printing of Enzymes on Textile Substrates as Functional Materials. Journal of Fiber Bioengineering and Informatics 7(4): 595-602.

13. Banat F, Al Bastaki N (2004) Treating dye wastewater by an integrated process of adsorption using activated carbon and ultrafiltration. Desalination 170(1): 69-75.

14. Barik S, Khandual A, Behera L, Badamali SK, Luximon A (2016) NanoM-Al-layered double hydroxide application to cotton for enhancing mechanical, UV protection and flame retardancy at low cytotoxicity level. Cellulose: Pp. 1-14.

15. Barnes L, Lea Greenwood G, Joergens C (2006) Ethical fashion: myth or future trend? Journal of Fashion Marketing and Management: An International Journal 10(3): 360-371.

16. Barnett C, Cloke P, Clarke N, Malpass A (2005) Consuming ethics: articulating the subjects and spaces of ethical consumption. Antipode 37(1): 23-45. 


\section{Current Trends in Fashion Technology \& Textile Engineering}

17. Battaglia M, Testa F, Bianchi L, Iraldo F, Frey M (2014) Corporate social responsibility and competitiveness within SMEs of the fashion industry: Evidence from Italy and France. Sustainability 6(2): 872893.

18. Beard ND (2008) The branding of ethical fashion and the consumer: a luxury niche or mass-market reality? Fashion theory 12(4): 447-467.

19. Benders J, Van Bijsterveld M (2000) Leaning on lean: the reception of a management fashion in Germany. New Technology, Work and Employment 15(1): 50-64.

20. Bhardwaj V, Fairhurst A (2010) Fast fashion: response to changes in the fashion industry. The International Review of Retail, Distribution and Consumer Research 20(1): 165-173.

21. Birtwistle G, Moore C (2006) Fashion adoption in the UK: a replication study.

22. Bruce M, Daly L, Towers N (2004) Lean or agile: a solution for supply chain management in the textiles and clothing industry? International Journal of Operations \& Production Management 24(2): 151-170.

23. Burke J (2015) Bangladesh garment workers suffer poor conditions two years after reform vows, New Delhi, India.

24. Burke M, Conn WD, Lutz RJ (1978) Using psychographic variables to investigate product disposition behaviors: pp. 321-326

25. Carr M, Chen MA, Tate J (2000) Globalization and home-based workers. Feminist Economics 6(3): 123-142.

26. Carrigan M, Attalla A (2001) The myth of the ethical consumer-do ethics matter in purchase behaviour? Journal of consumer marketing 18(7): 560-577.

27. Cavaco Paulo A, Gubitz G (2003) Textile processing with enzymes, Elsevier.

28. Chen HL, Burns LD (2006) Environmental analysis of textile products. Clothing and Textiles Research Journal 24(3): 248-261.

29. Chen M, Sebstad J, O'Connell L (1999) Counting the invisible workforce: the case of homebased workers. World development 27(3): 603-610.

30. Choi TM, Lo CK, Wong CW, Yee RW, Chan Ty, et al. (2012) The consumption side of sustainable fashion supply chain: Understanding fashion consumer eco-fashion consumption decision. Journal of Fashion Marketing and Management: An International Journal 16(2): 193-215.

31. Choi TM, Lo CK, Wong CW, Yee RW, Pui Yan Ho, et al. (2012) A Five-R analysis for sustainable fashion supply chain management in Hong Kong: a case analysis. Journal of Fashion Marketing and Management: An International Journal 16(2): 161-175

32. Choudhury AR (2014) Roadmap to Sustainable Textiles and Clothing: pp. 1-39.

33. Ciardelli G, Capannelli G, Bottino A (2000) Ozone treatment of textile wastewaters for reuse. Water Science and Technology 44(5): 61-67.

34. Clark H (2008a) SLOW+ FASHION-an Oxymoron-or a Promise for the Future...? Fashion theory 12(4): 427-446.

35. Clark H (2008b) SLOW+ FASHION-an Oxymoron-or a Promise for the Future...? Fashion theory 12(4): 427-446.

36. Connell KYH (2010) Internal and external barriers to eco-conscious apparel acquisition. International Journal of Consumer Studies 34(3): 279-286

37. Connolly J, Shaw D (2006) Identifying fair trade in consumption choice. Journal of strategic marketing 14(4): 353-368.

38. Correia VM, Stephenson T, Judd SJ (1994) Characterisation of textile wastewaters-a review. Environmental technology 15(10): 917-929.
39. Crum M, Poist R, Carter CR, Liane Easton P (2011) Sustainable supply chain management: evolution and future directions. International journal of physical distribution \& logistics management 41(1): 46-62.

40. Cupit M (1996) Opportunities and barriers to textile recycling, AEA Technology, Recycling Advisory Unit.

41. De Brito MP, Carbone V, Blanquart CM (2008) Towards a sustainable fashion retail supply chain in Europe: Organisation and performance. International Journal of Production Economics 114(2): 534-553.

42. De Coverly E, McDonagh P, O’Malley L, Patterson M (2008) Hidden mountain: the social avoidance of waste. Journal of Macromarketing 28(3): 289-303.

43. De Smet D, Weydts D, Vanneste M (2015) Sustainable Apparel Production, Processing and Recycling: p. 1.

44. Dubas ST, Kumlangdudsana P, Potiyaraj P (2006) Layer-by-layer deposition of antimicrobial silver nanoparticles on textile fibers. Colloids and Surfaces A: Physicochemical and Engineering Aspects 289(1): 105-109.

45. Eckerberg K, Nilsson M (2013) Environmental policy integration in practice: Shaping institutions for learning, Routledge.

46. Eder Hansen J (2015) Op-Ed | The Fashion Industry Must Network to Create Change, BOF.

47. Fersi C, Dhahbi M (2008) Treatment of textile plant effluent by ultrafiltration and/or nanofiltration for water reuse. Desalination 222(1): 263-271.

48. Fersi C, Gzara L, Dhahbi M (2005) Treatment of textile effluents by membrane technologies. Desalination 185(1): 399-409.

49. Finnveden G, Nilsson M (2005) Site-dependent Life-Cycle Impact Assessment in Sweden (5 pp). The International Journal of Life Cycle Assessment 10(4): 235-239.

50. Fletcher K (2009) Systems change for sustainability in textiles. Sustainable textiles: Life cycle and environmental impact, 369.

51. Fletcher K (2010) Slow fashion: An invitation for systems change Fashion Practice 2(2): 259-265.

52. Fletcher K (2012) Durability, fashion, sustainability: The processes and practices of use. Fashion Practice 4(2): 221-238.

53. Fletcher K (2013) Sustainable fashion and textiles: design journeys, Routledge.

54. Gaehr F, Hermanutz F, Oppermann W (1994) Ozonation-an important technique to comply with new German laws for textile wastewater treatment. Water Science and Technology 30(3): 255-263.

55. Gardetti MA, Muthu SS (2015) Handbook of sustainable luxury textiles and fashion, Springer

56. Gardetti MA, Torres AL (2013) Sustainability in fashion and textiles: values, design, production and consumption, Greenleaf Publishing.

57. Georgiou D, Melidis P, Aivasidis A, Gimouhopoulos K (2002) Degradation of azo-reactive dyes by ultraviolet radiation in the presence of hydrogen peroxide. Dyes and pigments 52(2): 69-78.

58. Gilhart J (2015) Op-Ed | Industry leaders need to have the courage to be more transparent, BOF.

59. Goethals F, Eufinger K, Vrieze Sd, Vanneste M, Schumann A, et al (2014) Eco-efficient hybrid coatings for durable textile applications by UV curing hybritex.

60. Gomes AP, Mano JF, Queiroz JA, Gouveia IC (2013) Layer-by-layer deposition of antimicrobial polymers on cellulosic fibers: a new strategy to develop bioactive textiles. Polymers for Advanced Technologies 24(11): 1005-1010. 


\section{Current Trends in Fashion Technology \& Textile Engineering}

61. Gross RA, Kalra B (2002) Biodegradable polymers for the environment. Science 297(5582): 803-807.

62. Harrelkas F, Azizi A, Yaacoubi A, Benhammou A, Pons MN (2009) Treatment of textile dye effluents using coagulation-flocculation coupled with membrane processes or adsorption on powdered activated carbon. Desalination 235(1): 330-339.

63. Harrison R, Newholm T, Shaw D (2005) The Ethical Consumer, Sage, London, UK.

64. Henriques A, Richardson J (2013) The triple bottom line: Does it all add up, Routledge.

65. Hepburn S (2015) Nike and Adidas show cautious support for ecofriendly dye technology.

66. Herva M, Franco A, Ferreiro S, Álvarez A, Roca E (2008) An approach for the application of the ecological footprint as environmental indicator in the textile sector. Journal of Hazardous Materials 156(1): 478-487.

67. ISO E (2006) ISO 14040 International Standard, International Organisation for Standardization, Geneva, Switzerland.

68. Jacoby J, Berning CK, Dietvorst TF (1977) What about disposition? The Journal of Marketing 41(2): 22-28.

69. Joy A, Sherry Jr JF, Venkatesh A, Wang J, Chan R (2012) Fast fashion, sustainability, and the ethical appeal of luxury brands. Fashion theory 16(3): 273-295

70. Karn SK, Harada H (2001) Surface water pollution in three urban territories of Nepal, India, and Bangladesh. Environ Manage 28(4) 483-496.

71. Khatri A, Peerzada MH, Mohsin M, White M (2015) A review on developments in dyeing cotton fabrics with reactive dyes for reducing effluent pollution. Journal of Cleaner Production 87: 50-57.

72. Kim DH (2011) A review of desalting process techniques and economic analysis of the recovery of salts from retentates. Desalination 270(1): 1-8.

73. Lau WJ, Ismail AF (2009) Polymeric nanofiltration membranes for textile dye wastewater treatment: preparation, performance evaluation, transport modelling, and fouling control-a review. Desalination 245(1): 321-348.

74. Lin SH, Chen ML (1997) Treatment of textile wastewater by chemical methods for reuse. Water research 31(4): 868-876.

75. Mahltig B, Fiedler D, Böttcher H (2004) Antimicrobial sol-gel coatings. Journal of sol-gel science and technology 32(1-3): 219-222.

76. Majumdar A, Mukhopadhyay S, Yadav R (2010) Thermal properties of knitted fabrics made from cotton and regenerated bamboo cellulosic fibres. International Journal of Thermal Sciences 49(10): 2042-2048.

77. Manchiraju S, Sadachar A (2014) Personal values and ethical fashion consumption. Journal of Fashion Marketing and Management 18(3): 357-374.

78. Marcucci M, Ciardelli G, Matteucci A, Ranieri L, Russo M (2002) Experimental campaigns on textile wastewater for reuse by means of different membrane processes. Desalination 149(1): 137-143.

79. Marcucci M, Nosenzo G, Capannelli G, Ciabatti I, Corrieri D, et al. (2001) Treatment and reuse of textile effluents based on new ultrafiltration and other membrane technologies. Desalination 138(1): 75-82.

80. Marcuccio M, Steccolini I (2005) Social and environmental reporting in local authorities: a new Italian fashion? Public Management Review 7(2): 155-176.

81. Marmagne 0, Coste C (1996) Color removal from textile plant effluents. American Dyestuff Reporter 85(4): 1-6.
82. McAfee A, Dessain V, Sjöman A (2007) Zara: IT for fast fashion, Harvard Business School.

83. Members G (2007) What is ecolabelling?, Global Ecolabelling Network.

84. Mohanty A, Misra M, Hinrichsen G (2000) Biofibres, biodegradable polymers and biocomposites: an overview. Macromolecular materials and Engineering 276(1): 1-24

85. Mohsin M, Ahmad SW, Khatri A, Zahid B (2013) Performance enhancement of fire retardant finish with environment friendly bio cross-linker for cotton. Journal of Cleaner Production 51: 191-195.

86. Morgan LR, Birtwistle G (2009) An investigation of young fashion consumers' disposal habits. International Journal of Consumer Studies 33(2): 190-198.

87. Nagurney A, Yu M (2012) Sustainable fashion supply chain management under oligopolistic competition and brand differentiation. International Journal of Production Economics 135(2): 532-540.

88. Naumczyk J, Szpyrkowicz L, Zilio Grandi F (1996) Electrochemical treatment of textile wastewater. Water Science and Technology 34(11): 17-24

89. Nawaz N, Nayak R (2015) Garment Manufacturing Technology. Woodhead Publishing, United Kingdom.

90. Nayak R, Khandual A, Jajpura L (2007) Ink-jet printing of textiles: The technology for tomorrow. Text Asia 38(7): 45-48.

91. Nayak R, Padhye R (2014) Functional Finishes for Textiles: Improving Comfort, Performance and Protection: pp. 361-386.

92. Nayak R, Padhye R (2014) Textiles and Fashion: Materials, Design and Technology: Pp. 799-822.

93. Nayak R, Padhye R (2015) Garment Manufacturing Technology, Elsevier.

94. Nayak R, Padhye R (2015) Garment Manufacturing Technology: pp $1-17$.

95. Ness B, Urbel Piirsalu E, Anderberg S, Olsson L (2007) Categorising tools for sustainability assessment. Ecological economics 60(3): 498508 .

96. Niinimäki K, Hassi L (2011) Emerging design strategies in sustainable production and consumption of textiles and clothing. Journal of Cleaner Production 19(16): 1876-1883.

97. Paprowicz J, Słodczyk S (1988) Application of biologically activated sorptive columns for textile waste water treatment. Environmental technology 9(4): 271-280.

98. Parkins W, Craig G (2006) Slow living, Berg.

99. Parsons S (2004) Advanced oxidation processes for water and wastewater treatment, IWA publishing.

100. Pedersen ERG, Andersen KR (2015) Sustainability innovators and anchor draggers: a global expert study on sustainable fashion. Journal of Fashion Marketing and Management 19(3): 315-327

101. Pedersen ERG, Gwozdz W (2014) From resistance to opportunity seeking: Strategic responses to institutional pressures for corporate social responsibility in the Nordic fashion industry. Journal of business ethics 119(2): 245-264.

102. Pekakis PA, Xekoukoulotakis NP, Mantzavinos D (2006) Treatment of textile dyehouse wastewater by $\mathrm{TiO} 2$ photocatalysis. Water research 40(6): 1276-1286.

103. Perry P, Towers N (2009) Determining the antecedents for a strategy of corporate social responsibility by small-and medium-sized 


\section{Current Trends in Fashion Technology \& Textile Engineering}

enterprises in the UK fashion apparel industry. Journal of Retailing and Consumer Services 16(5): 377-385.

104. Raghu S, Basha CA (2007) Chemical or electrochemical techniques, followed by ion exchange, for recycle of textile dye wastewater. Journal of Hazard Mater 149(2): 324-330.

105. Rebitzer G, Ekvall T, Frischknecht R, Hunkeler D, Norris G, et al. (2004) Life cycle assessment: Part 1: Framework, goal and scope definition, inventory analysis, and applications. Environment international 30(5): 701-720.

106. Reinhard K (2013) Working conditions in the global fashion industry, Huelva, Spain.

107. Roberts S (2003) Supply chain specific? Understanding the patchy success of ethical sourcing initiatives. Journal of business ethics 44(2): 159-170.

108. Robinson T, McMullan G, Marchant R, Nigam P (2001) Remediation of dyes in textile effluent: a critical review on current treatment technologies with a proposed alternative. Bioresour technol 77(3): 247-255.

109. Roy Choudhury AK (2013) Green chemistry and the textile industry. Textile Progress 45(1): 3-143.

110. Sahinkaya E, Uzal N, Yetis U, Dilek FB (2008) Biological treatment and nanofiltration of denim textile wastewater for reuse. Journal of Hazardous Materials 153(3): 1142-1148.

111. Salazar Gámez L, Crespi Roseli M, Salazar R (2009) Treatment of textile waste water by membrane bioreactor. Ingeniería y Desarrollo (26): 83-99.

112. Samanta KK, Jassal M, Agrawal AK (2009) Improvement in water and oil absorbency of textile substrate by atmospheric pressure cold plasma treatment. Surface and Coatings Technology 203(10): 13361342 .

113. Samanta KK, Jassal M, Agrawal AK (2010) Antistatic effect of atmospheric pressure glow discharge cold plasma treatment on textile substrates. Fibers and polymers 11(3): 431-437.

114. Shen B, Zheng JH, Chow PS, Chow KY (2014) Perception of fashion sustainability in online community. The Journal of The Textile Institute 105(9): 971-979.

115. Shishoo R (2007) Plasma Technologies for Textiles, Elsevier.

116. Singha K (2012) A review on coating \& lamination in textiles: processes and applications. American Journal of Polymer Science 2(3): 39-49.

117. Soares JC, Moreira PR, Queiroga AC, Morgado J, Malcata FX, et al (2011) Application of immobilized enzyme technologies for the textile industry: a review. Biocatalysis and Biotransformation 29(6): 223-237.
118. Steinhart Y, Ayalon O, Puterman H (2013) The effect of an environmental claim on consumers' perceptions about luxury and utilitarian products. Journal of Cleaner Production 53: 277-286.

119. Suksaroj C, Heran M, Allegre C, Persin F (2005) Treatment of textile plant effluent by nanofiltration and/or reverse osmosis for water reuse. Desalination 178(1): 333-341.

120. Tang C, Chen V (2002) Nanofiltration of textile wastewater for water reuse. Desalination 143(1): 11-20.

121. Thailand $H$ (2002) Impact of the economic crisis on homeworkers in Thailand, Home Net Thailand.

122. Treffry Goatley K, Buckley C, Groves G (1983) Reverse osmosis treatment and reuse of textile dyehouse effluents. Desalination 47(1): 313-320.

123. Vachon S, Klassen RD (2008) Environmental management and manufacturing performance: The role of collaboration in the supply chain. International Journal of Production Economics 111(2): 299315.

124. Wang M, Webber M, Finlayson B, Barnett J (2008) Rural industries and water pollution in China. Journal of Environmental Management 86(4): 648-659.

125. Willmott N, Guthrie J, Nelson G (1998) The biotechnology approach to colour removal from textile effluent. Journal of the Society of Dyers and Colourists 114(2): 38-41.

126. Wu C, Maurer C, Wang Y, Xue S, Davis DL (1999) Water pollution and human health in China. Environ Health Perspect 107(4): 251-256.

127. Xing Y, Yang X, Dai J (2007) Antimicrobial finishing of cotton textile based on water glass by sol-gel method. Journal of sol-gel science and technology 43(2): 187-192.

128. Yaman N, Özdoğan E, Seventekin N, Ayhan H (2009) Plasma treatment of polypropylene fabric for improved dyeability with soluble textile dyestuff. Applied surface science 255(15): 6764-6770.

129. Yang CL, Lin SP, Chan Yh, Sheu C (2010) Mediated effect of environmental management on manufacturing competitiveness: an empirical study. International Journal of Production Economics 123(1): 210-220.

130. Yardley J (2013) Report on deadly factory collapse in Bangladesh finds widespread blame. New York Times 22: 1-3.

131. Zadek S, Evans R, Pruzan P (2013) Building corporate accountability: Emerging practice in social and ethical accounting and auditing, Routledge.
Your next submission with Juniper Publishers will reach you the below assets

- Quality Editorial service

- Swift Peer Review

- Reprints availability

- E-prints Service

- Manuscript Podcast for convenient understanding

- Global attainment for your research

- Manuscript accessibility in different formats

( Pdf, E-pub, Full Text, Audio)

- Unceasing customer service

Track the below URL for one-step submission https://juniperpublishers.com/online-submission.php 